\title{
Purine Nucleoside Phosphorylase
}

\author{
ALLOSTERIC REGULATION OF A DISSOCIATING ENZYME*
}

(Received for publication, October 9, 1990)

\author{
Patricia A. Ropp and Thomas W. Traut $\ddagger$ \\ From the Department of Biochemistry and Biophysics, University of North Carolina School of Medicine, Chapel Hill, \\ North Carolina 27599-7260
}

\begin{abstract}
Purine nucleoside phosphorylase (EC 2.4.2.1) from bovine spleen is a trimeric enzyme that readily dissociates to the monomer. Dilution of enzyme from 20 to $0.02 \mu \mathrm{g}$ of protein $/ \mathrm{ml}$ is accompanied by a greater than 50 -fold increase in the specific activity $\left(v_{\text {trimer }}=0.23\right.$ $\left.\mathrm{nmol} / \mathrm{min} / \mu \mathrm{g} ; v_{\text {monomer }}=12.5 \mathrm{nmol} / \mathrm{min} / \mu \mathrm{g}\right)$. Gel permeation chromatography in the presence of the substrate phosphate shows the enzyme to be predominantly trimeric at $50 \mathrm{mM} P_{\mathrm{i}}$ and predominantly monomeric at $100 \mathrm{~mm} P_{i}$, when experiments are done at $24^{\circ} \mathrm{C}$. No significant dissociation was observed at $4^{\circ} \mathrm{C}$ with $P_{i}$ or at either temperature with the substrate inosine. As measured by dissociation, the $L_{0.5}$ for $P_{i}$ is $88 \mathrm{mM}$ and thus significantly higher than the $K_{m}$ of $3.1 \mathrm{~mm}$ for $P_{i}$. Enzyme activity as a function of phosphate concentration showed negative cooperativity, but the conformational response measured by the change in native $M_{\mathrm{r}}$ during dissociation showed positive cooperativity toward $P_{i}$. These data support a model for two separate phosphate binding sites on the enzyme.

The activity and stability of purine nucleoside phosphorylase are quite sensitive to the concentration of the enzyme as well as appropriate substrates. Although the monomer is interpreted as being a fully active form of the enzyme, the data in general are most consistent with the enzyme functioning in vivo as a regulated trimer.
\end{abstract}

Purine nucleoside phosphorylase (PNP ${ }^{1}$ EC 2.4.2.1) catalyzes the reversible phosphorolysis of inosine and guanosine nucleosides and deoxynucleosides to form the base and deoxyribose-1-P. Due to the normal cellular concentrations of the reactants, the eukaryotic enzyme is considered to be mainly catabolic, converting purine nucleosides to their base $(1,2)$. The enzyme from most eukaryotic sources has been described as a trimer (3-12), although it has also been reported as a dimer in bovine brain (13), human erythrocytes (14), and rabbit brain (15), and as a monomer in rabbit liver (16). Kinetic studies have sometimes reported negative cooperativity with phosphate $(8,17-20)$. Some ambiguity as to the significance of such cooperativity has arisen since other stud-

* This work was supported by Grant DMB8716647 from the National Science Foundation. The costs of publication of this article were defrayed in part by the payment of page charges. This article must therefore be hereby marked "advertisement" in accordance with 18 U.S.C. Section 1734 solely to indicate this fact.

† To whom correspondence should be addressed.

${ }_{1}^{1}$ The abbreviations used are: PNP, purine nucleoside phosphorylase; $S_{0.5}$, the substrate concentration required for half-maximal activity; $L_{0.5}$, the ligand concentration required for half-maximal dissociation; $n_{\mathrm{H}}$, Hill coefficient. ies have reported no cooperativity with phosphate $(9,13,21$, 22).

The three-dimensional structure for human PNP was recently reported (23), with some structural evidence for two distinct phosphate-binding sites. The present work shows physical and kinetic studies that are also best explained by two phosphate binding sites: the catalytic site plus a potential regulatory site.

\section{EXPERIMENTAL PROCEDURES}

\section{Materials}

Inosine, xanthine oxidase, Trizma (Tris base) buffer, and crystalline purine nucleoside phosphorylase (calf spleen) were from Sigma. Sephacryl S-300 resin was from Pharmacia LKB Biotechnology Inc.; molecular weight standards were from Boehringer-Mannheim. All other reagents were of the best grade available.

\section{Methods}

Enzyme Assay-The standard assay was based on the spectrophotometric method of Kalckar (24) and performed in a 1-ml final volume containing $50 \mathrm{mM}$ citrate $\left(\mathrm{pH} 6.5\right.$ at $24^{\circ} \mathrm{C}$ ), 0.2 units of xanthine oxidase, the coupling enzyme, and PNP at concentrations denoted in the figures. In enzyme dilution experiments (Fig. 1), xanthine oxidase was present at a minimum of 0.2 units or at 3 times the activity of PNP when PNP was at higher concentrations. The substrates were normally at fixed concentrations (10 $\mathrm{mM} \mathrm{P}_{\mathrm{i}}$ and $0.5 \mathrm{mM}$ inosine) or at concentrations shown in the figures. The formation of the final product uric acid was measured by the optical density at $293 \mathrm{~nm}(\epsilon=$ 12,500 ) on a Beckman model 25 recording dual beam spectrophotometer. The reference cuvette contained the reaction mixture minus PNP. All kinetic values were determined from the linear portion of the continuously recorded absorbance. All the kinetic studies have been reproduced, and in the figures shown the data points are normally the average of three determinations.

PNP was obtained as a suspension in $3.2 \mathrm{M}$ ammonium sulfate, in which form it was fairly stable. When examined by gel electrophoresis (in the presence of sodium dodecyl sulfate) this enzyme preparation normally showed one distinct band and was judged to be greater than $95 \%$ pure. The mobility of PNP is consistent with a subunit $M_{\mathrm{r}}$ of 30,000 . PNP was normally prepared fresh by desalting the ammonium sulfate suspension. This was done by diluting a sample with buffer until the enzyme was totally dissolved and then running an aliquot through a Sephadex G-25 column maintained in $20 \mathrm{mM}$ Tris buffer. Such enzyme is referred to as freshly prepared in this study. Protein was determined by the modified Bradford assay (25) using bovine serum albumin as a standard.

Molecular Weight Determination-The enzyme preparation used, when examined by sodium dodecyl sulfate gel electrophoresis was at least $95 \%$ pure and had a subunit $M_{\mathrm{r}}$ of 30,000 (data not shown). The native $M_{\mathrm{r}}$ of the enzyme was determined by gel permeation chromatography with a Sephacryl S-300 column $(1 \times 110 \mathrm{~cm})$ that was operated either at room temperature $\left(24^{\circ} \mathrm{C}\right)$ or at $4^{\circ} \mathrm{C}$. The column was equilibrated in buffer ( $50 \mathrm{~mm}$ sodium citrate, $250 \mathrm{mM} \mathrm{KCl}, \mathrm{pH}$ $6.5) \pm$ the appropriate concentration of effector ligand and operated at a flow rate of $4.1 \mathrm{ml} / \mathrm{h}$. The enzyme sample contained $2 \mu \mathrm{g}$ of freshly prepared PNP in a total volume of $200 \mu \mathrm{l}$, which always included three internal $M_{\mathrm{r}}$ standards: ferritin $(440,000)$, aldolase 
$(158,000)$, and chymotrypsinogen $(25,000)$. The observed $M_{\mathrm{r}}$ for PNP was always determined from the three internal reference proteins.

Enzyme Stability-For the preincubation stability studies the enzyme was diluted into citrate buffer $(\mathrm{pH}$ 6.5) containing substrates as potential stabilizing ligands as shown. The concentration of enzyme during the preincubation varied over a range from 0.19 to 2.25 $\mu \mathrm{g} / \mathrm{ml}$ as shown in the figure. Except where indicated otherwise, the preincubation was always carried out at $24^{\circ} \mathrm{C}$. For the dilution studies (Fig. 1), it was desirable to keep the volume of enzyme added to the reaction constant. Therefore, stock enzyme was diluted into citrate buffer \pm ligand and assayed $30 \mathrm{~s}$ later.

Calculations-The change in specific activity of purine nucleoside phosphorylase as a function of enzyme concentration is consistent with a change in the polymeric state of the enzyme. As reviewed by Kurganov (26), two approaches may be used to evaluate the intrinsic $K_{d}$ for the dissociation of the polymer. If the dissociation and reassembly is best described by

$$
3 \rightleftarrows 1+1+1
$$

then the appropriate expression relating activity to enzyme concentration is given by

$$
a=a_{3}+\sqrt[3]{\frac{\left(a_{1}-a_{3}\right)^{2}}{3 K_{d(3-1)}}} \cdot \sqrt[3]{\frac{\left(a_{1}-a\right)}{[E]_{0}^{2}}}
$$

where $a$ is the observed specific activity, and $a_{3}$ and $a_{1}$ are the specific activities of trimer and monomer, respectively. However, if this process is best described by

$$
3 \rightleftarrows 2+1 ; 2 \rightleftarrows 1+1
$$

then, if the two equilibria are similar, the appropriate expression would be

$$
a=a_{3}+\sqrt{\frac{\left(a_{1}-a_{3}\right)}{2 K_{d(3-2 ; 2-1)}}} \cdot \sqrt{\frac{\left(a_{1}-a\right)}{[E]_{0}}} .
$$

Cooperativity for binding phosphate as measured by change in native $M_{\mathrm{r}}$ for the enzyme during dissociation can be calculated from the relationship

$$
n_{\mathrm{H}}=\frac{\log 81}{\log \left(L_{0.9} / L_{0.1}\right)}
$$

where $L_{0.1}$ and $L_{0.9}$ are the concentrations of phosphate required for 10 and $90 \%$ dissociation of the PNP trimer, respectively.

\section{RESULTS}

Measurement of the specific activity of PNP as a function of enzyme concentration (Fig. 1) showed a significant increase



FlG. 1. Change in the specific activity of purine nucleoside phosphorylase with dilution of the enzyme. Enzyme was freshly prepared and diluted in citrate buffer only $(O)$, or in buffer plus 50 $\mu \mathrm{M}$ inosine $(\square)$, or $50 \mathrm{mM} \mathrm{P}_{\mathrm{i}}(\bullet)$. as enzyme was diluted from a starting concentration in the reaction of $110 \mu \mathrm{g} / \mathrm{ml}\left(3.7 \cdot 10^{-6} \mathrm{M}\right)$ to a concentration of 0.019 $\mu \mathrm{g} / \mathrm{ml}\left(6.3 \cdot 10^{-10} \mathrm{M}\right)$. The increase in specific activity was greater than 50 -fold for enzyme diluted into buffer alone and was greater than 70-fold for enzyme in the presence of $50 \mathrm{mM}$ $P_{i}$. When enzyme was diluted in the presence of substrate, the reaction mix for the assay was appropriately compensated to keep final substrate concentrations constant. The effect of substrate ligands is apparent when enzyme was most dilute. The most concentrated enzyme had a specific activity of about $0.23 \mathrm{nmol} / \mathrm{min} / \mu \mathrm{g}$, while the more diluted enzyme reached a stable activity of $12.5 \mathrm{nmol} / \mathrm{min} / \mu \mathrm{g}$ (buffer only), $17.6 \mathrm{nmol} /$ $\mathrm{min} / \mu \mathrm{g}\left(50 \mathrm{mM} \mathrm{P}_{\mathrm{i}}\right)$, or $22.8 \mathrm{nmol} / \mathrm{min} / \mu \mathrm{g}(50 \mu \mathrm{M}$ inosine $)$. Similar studies with guanosine as the nucleoside effector at $50 \mu \mathrm{M}$ (data not shown) showed a comparable ligand effect on the increase in specific activity with enzyme dilution; the activity of diluted enzyme was $17.8 \mathrm{nmol} / \mathrm{min} / \mu \mathrm{g}$. While the activity profiles shown in Fig. 1 are consistent with enzyme existing as a trimer at high protein concentration $\left(>10^{-6} \mathrm{M}\right)$ or as a monomer when significantly diluted $\left(<10^{-8} \mathrm{M}\right)$, corresponding molecular weight studies were difficult to perform since the enzyme does not remain as stable in solution over the time period of a chromatography experiment when the enzyme becomes too diluted.

However, changes in native molecular weight could be determined in the presence of an effector ligand, with the enzyme at a constant initial concentration of $10 \mu \mathrm{g} / \mathrm{ml}(3.3$. $\left.10^{-7} \mathrm{M}\right)$. Example elution profiles of such experiments are shown in Fig. 2, where the enzyme eluted as a trimer in the presence of $60 \mathrm{mM} \mathrm{P}_{\mathrm{i}}$ (Fig. $2 A$, apparent $M_{\mathrm{r}}=86,000$ ) or as a monomer in the presence of $100 \mathrm{mM} \mathrm{P}_{\mathrm{i}}$ (Fig. $2 B$, apparent $M_{\mathrm{r}}$ $=31,000)$. When the native molecular weight of PNP was examined by gel permeation chromatography (Fig. 2), the enzyme always migrated as a single symmetric peak, and in the presence of increasing $\mathrm{P}_{\mathrm{i}}$, the enzyme was steadily converted to the dissociated monomeric form (Fig. 3). This observed dissociation is dependent on temperature, since no significant change in $M_{\mathrm{r}}$ was observed at $4{ }^{\circ} \mathrm{C}$, even at $1 \mathrm{MP} \mathrm{P}_{\mathrm{i}}$ (Fig. 3). Since chromatography was routinely performed with

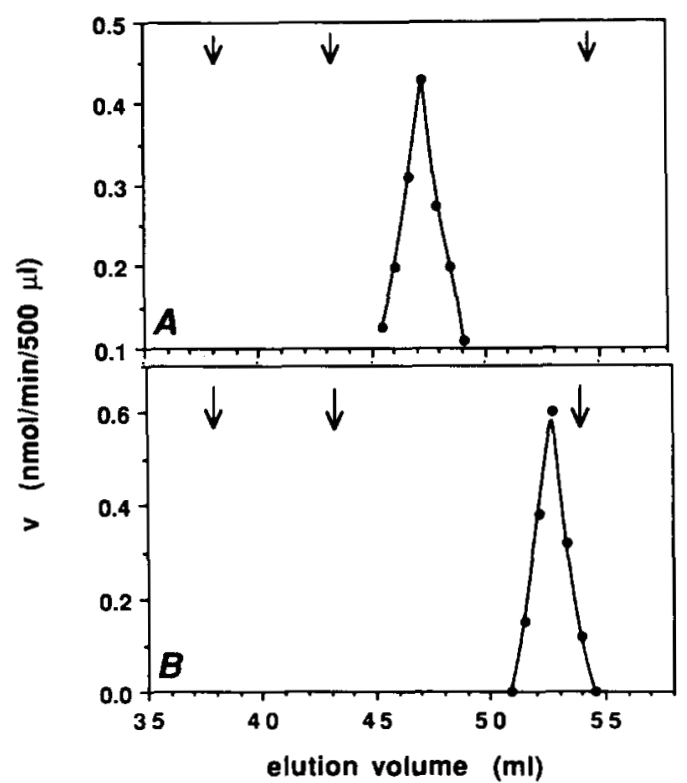

FIG. 2. Elution profiles for purine nucleoside phosphorylase during gel permeation chromatography. Enzyme samples contained the internal $M_{\mathrm{r}}$ standards, indicated by arrows (from left to right: ferritin, 440,00; aldolase, 158,000; chymotrypsinogen, 25,000). The concentration of $P_{i}$ was $60 \mathrm{~mm}(A)$ or $100 \mathrm{~mm}(B)$. 


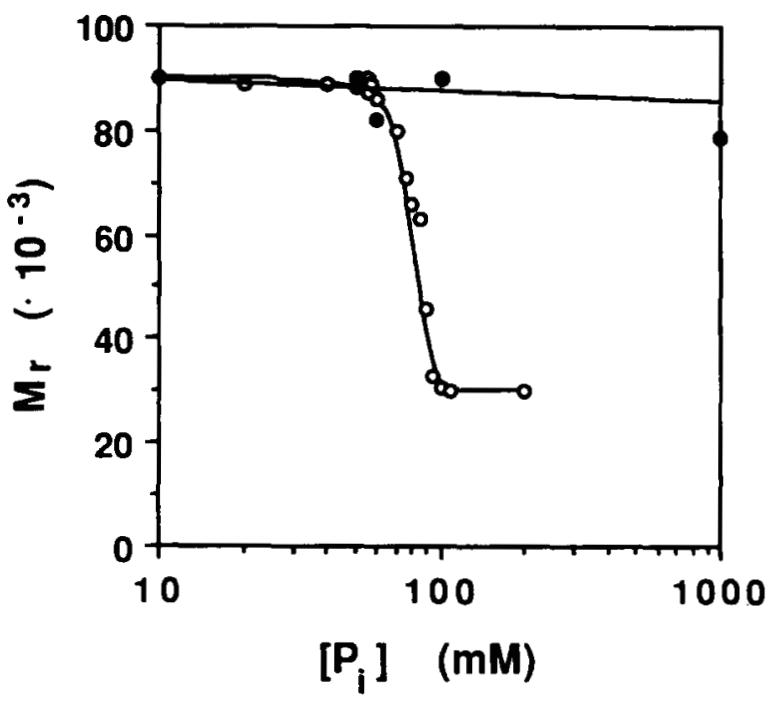

FIG. 3. Dissociation of purine nucleoside phosphorylase in response to phosphate. Gel permeation chromatography was performed as described for Fig. 2 with column buffer containing phosphate as shown. Chromatography was done at $24{ }^{\circ} \mathrm{C}(\mathrm{O})$ or at $4{ }^{\circ} \mathrm{C}$ $(\bullet)$.

column buffers containining $250 \mathrm{mM} \mathrm{KCl}$, control experiments were done to determine if simple ionic strength could lead to dissociation. With phosphate at $50 \mathrm{mM}$ and $\mathrm{KCl}$ increased to $400 \mathrm{mM}$, there was no measurable dissociation of the PNP trimer at $24^{\circ} \mathrm{C}$ (not shown); alternatively, with $\mathrm{KCl}$ at only $85 \mathrm{mM}$ and with phosphate at $100 \mathrm{mM}$, the enzyme dissociated completely.

Comparing the results of Figs. 1 and 3 shows that at the higher concentrations of PNP used in the experiment of Fig. 1 , the enzyme should normally exist as a trimer (in the absence of effector ligands). But addition of $P_{i}$ to enzyme at a concentration of PNP favoring trimer led to complete dissociation. When examined in the presence of inosine up to $10 \mathrm{mM}$, the observed $M_{\mathrm{r}}$ of PNP did not vary from the trimeric form (data not shown). Inspection of Fig. 3 shows that the allosteric response, as measured by dissociation, is extremely sharp and is essentially complete over a relatively narrow range of $P_{i}$ concentration. The Hill coefficient for this process yields a value of 10.8 , suggesting an unusual degree of positive cooperativity in the dissociation process of an enzyme that is initially quite stable as a trimer.

When the enzyme was tested for cooperativity against phosphate as a substrate, negative cooperativity was observed (Fig. $4 A$ ). Because of the apparent complexity of the above kinetic plots, the data were reanalyzed by Hill plots to measure the cooperativity more exactly; the diagonal reference line in Fig. $4 B$ has a slope of 1.0. Negative cooperativity with $n_{\mathrm{H}}$ equal to about 0.5 is evident at $P_{i}$ below $1 \mathrm{mM}$ (Fig. $4 B$ ), while no cooperativity is apparent at higher concentrations of $P_{i}$, where the enzyme has attained normal activity. The same cooperativity was seen when the enzyme was 100 -fold more concentrated (Fig. $4 B$ ), although the curve is displaced downward, indicating a lower affinity for $\mathrm{P}_{\mathrm{i}}$ for the more concentrated enzyme. Thus, the transition of PNP in response to $P_{i}$ as measured kinetically (Fig. 4) occurs at a much lower concentration of $\mathrm{P}_{\mathrm{i}}$ than the conformational change of PNP in response to $P_{i}$ as measured by dissociation (Fig. 3 ).

As mentioned above, the stability of PNP in solution is responsive to substrate ligands as well as to enzyme concentration. This was examined at different concentrations of enzyme and under three different conditions: no ligands; plus inosine; plus phosphate (Fig. 5). In the experiment of Fig. 5,


FIG. 4. Kinetics of purine nucleoside phosphorylase versus phosphate. $A$, Lineweaver-Burk plot; $B$, Hill plot. The concentration of enzyme was $0.06 \mu \mathrm{g} / \mathrm{ml}\left(2.0 \cdot 10^{-9} \mathrm{M}\right)(\odot)$ or $6 \mu \mathrm{g} / \mathrm{ml}\left(2.0 \cdot 10^{-7} \mathrm{M}\right)$ (O).

enzyme was preincubated, for the times shown, at three different concentrations of enzyme \pm one substrate. Activity was then measured in the standard assay. The initial specific activity was highest for enzyme preincubated at a low concentration of protein (Fig. 5, $A-C$ ). This specific activity declined as PNP was preincubated at higher enzyme concentrations (Fig. 5, $D-F$ and $G-I$ ). The most dilute enzyme was the least stable and showed a loss of activity in a biphasic pattern for the 60 -min preincubation period, whether or not potential stabilizing ligands were present (Fig. $5, A-C$ ). At an intermediate concentration of enzyme, continuing loss of activity was significant only for PNP preincubated without ligands (Fig. $5 D)$. At both intermediate and high concentrations of PNP, enzyme preincubated with phosphate had a slightly higher specific activity than enzyme preincubated with inosine or without substrate. Although inosine did not increase the enzyme's specific activity, the enzyme was very stable in the presence of inosine, with no significant decline from 5 to 60 $\min$.

Temperature also affects the initial enzyme activity as well as the stability of this activity. As shown in Fig. 6, the initial activity is $20 \%$ lower at the earliest measurement when the enzyme had been diluted into buffer at $4{ }^{\circ} \mathrm{C}$ as compared with buffer at $24{ }^{\circ} \mathrm{C}$, although at $4{ }^{\circ} \mathrm{C}$ the activity then remained 




FIG. 5. Stability of purine nucleoside phosphorylase as a function of enzyme concentration and ligand. During the preincubation the concentration of PNP was: $A-C, 0.19 \mu \mathrm{g} / \mathrm{ml}\left(6.3 \cdot 10^{-9}\right.$ M); $D-F, 0.94 \mu \mathrm{g} / \mathrm{ml}\left(3.1 \cdot 10^{-8} \mathrm{M}\right) ; G-I, 2.25 \mu \mathrm{g} / \mathrm{ml}\left(7.5 \cdot 10^{-8} \mathrm{M}\right)$. In the assay the concentration of enzyme was reduced $50 \%$. When present, inosine was at $50 \mu \mathrm{M}(B, E, H)$ and phosphate at $50 \mathrm{mM}(C$, $F, I)$.

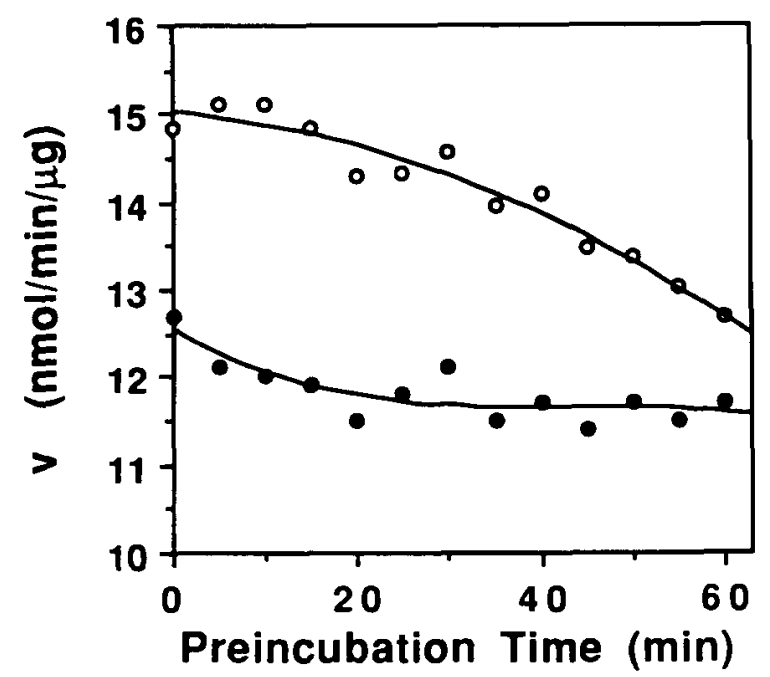

FIG. 6. Stability of purine nucleoside phosphorylase activity as a function of temperature at $24^{\circ} \mathrm{C}(0)$ or at $4^{\circ} \mathrm{C}(0)$. The enzyme was preincubated at $0.3 \mu \mathrm{g} / \mathrm{ml}$ in citrate buffer for the times shown and assayed at a final concentration of $0.15 \mu \mathrm{g} / \mathrm{ml}(5.0$. $\left.10^{-9} \mathrm{M}\right)$.

very stable. It is worth noting that for enzyme preincubated at $24{ }^{\circ} \mathrm{C}$ the activity is quite stable for the first $15 \mathrm{~min}$. This is significant since the enzyme assays were done at this temperature, so that results showing changes are probably completely due to the preincubation conditions and do not reflect further instability during the assay itself.

In the above experiments it became apparent that the response time of the enzyme after being added to the assay mixture also varied. Initially, after the components were mixed, the enzyme appeared to be inactive, demonstrating a readily measurable lag time before a linear progress curve developed. Such lag times are shown in Fig. 7 at two different concentrations of enzyme and with different ligands as in Fig. 5. Highly diluted enzyme in buffer alone, or in the presence of phosphate, had a greater lag time than enzyme preincubated with inosine (Fig. $7 A$ ). Enzyme preincubated with ino-

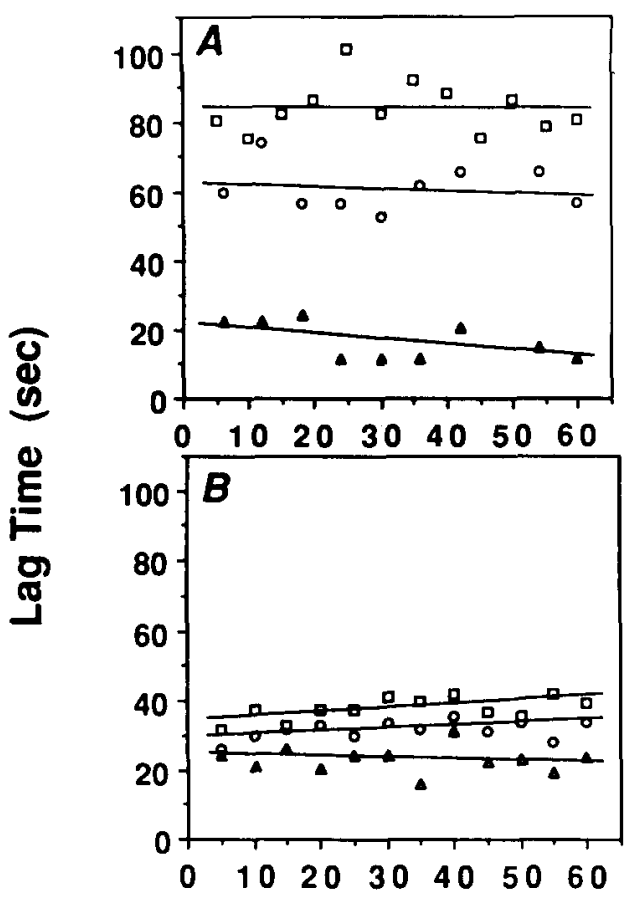

\section{Preincubation Time ( $\min )$}

FIG. 7. Lag times in the appearance of enzyme activity for PNP preincubated under different conditions. The enzyme was preincubated at a final concentration of $0.19 \mu \mathrm{g} / \mathrm{ml}\left(6.3 \cdot 10^{-9} \mathrm{M}\right)(A)$ or $2.25 \mu \mathrm{g} / \mathrm{ml}\left(7.5 \cdot 10^{-8} \mathrm{M}\right)(B)$. The preincubation occurred in buffer alone $(O)$ or in the presence of $50 \mu \mathrm{M}$ inosine $(\mathbf{A})$ or $50 \mathrm{mM} \mathrm{P}_{\mathrm{i}}(\square)$.

sine consistently showed the shortest lag times, but at higher concentrations of PNP the difference for enzyme preincubated in buffer alone or with $\mathrm{P}_{\mathrm{i}}$ became less significant (Fig. $7, A$ and $B$ ).

The data from Fig. 1 may be used to calculate a $K_{d}$ for the dissociation of the enzyme trimer. In these studies it is not clear if the trimer spontaneously dissociates to monomers $\left(K_{d(3-1)}\right)$ or whether dimers are an obligatory intermediate $\left(K_{d(3-2 ; 2-1)}\right)$. The latter is much more probable, but the observation of enzyme eluting with an apparent $M_{\mathrm{r}}$ of 60,000 (= to dimer) does not in fact establish that dimers were a significant species, since such an observation could also result from a rapid equilibrium between trimers and monomers producing a statistical average elution time equal to dimers. This last explanation most likely accounts for our observation of sharp enzyme peaks (as seen in Fig. 2) eluting at various apparent $M_{\mathrm{r}}$ between 90,000 and 30,000 (Fig. 3). Therefore two approaches for calculating $K_{d}$, taken from Kurganov (26), are shown in Table I. Both the value for $K_{d(3-1)}=1.4 \cdot 10^{-17} \mathrm{M}$ and for $K_{d(3 ; 2 ; 2-1)}=3.6 \cdot 10^{-9} \mathrm{M}$ support the observation that the trimer is quite stable and dissociates only at considerable enzyme dilution (Fig. 1) or in response to an allosteric ligand (Figs. 2 and 3).

Also shown are the two affinity constants for PNP toward the substrate $P_{i}$. As determined by standard kinetics with the substrate (Fig. 4), $S_{0.5}=3.1 \mathrm{~mm}$, showing that the enzyme catalytic site is half-saturated at physiological concentrations of $P_{i}$. However, physical studies following the change in $M_{\mathrm{r}}$ as a function of $\mathrm{P}_{\mathrm{i}}$ (Fig. 3 ) showed that $L_{0.5}=88 \mathrm{mM}$. Thus, enzyme activity became saturated at a much lower concentration of $\mathrm{P}_{\mathrm{i}}$ than did the conformational change that produced dissociation. Also important are the results (Table I) showing that totally different cooperativity patterns were seen for $P_{i}$ when measured by activity or by change in dissociation. 
TABLE I

Physical and kinetic constants for purine nucleoside phosphorylase

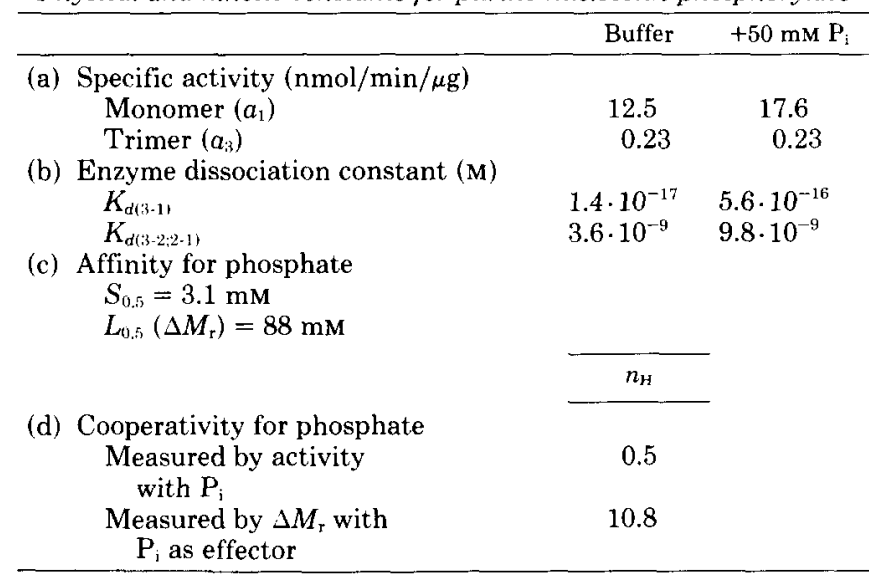

Negative cooperativity $\left(n_{\mathrm{H}}=0.5\right)$ was seen for the binding of phosphate at the catalytic site; positive cooperativity $\left(n_{\mathrm{H}}=\right.$ 10.8) was observed for phosphate at the allosteric site.

\section{DISCUSSION}

Polymer Dissociation-The dilution curves (Fig. 1) clearly show that at concentrations of PNP below $3 \mu \mathrm{g} / \mathrm{ml}\left(10^{-7} \mathrm{M}\right)$ the enzyme exhibited a significant increase in specific activity, consistent with a conformational change stabilized by dissociation. In buffer alone, the increase in specific activity was over 50-fold, while in the presence of $50 \mathrm{mM} \mathrm{P}_{\mathrm{i}}$ this increase was over 70 -fold. Since the assay mixture was always adjusted to maintain substrates at a constant concentration for the experiment, then the effect of substrates seen in the higher curves (Fig. 1) represents the induction or stabilization of a more optimal conformation. For dilute enzyme the final specific activity was significantly increased in the presence of either substrate as a stabilizing ligand.

Essentially base-line resolution was possible for the position of trimer and monomer when examined by gel filtration chromatography (Fig. 2), since in all such studies the enzyme eluted as a single sharp peak even when the observed $M_{\mathrm{r}}$ value did not correspond to an integral number of subunits. The decrease in the observed $M_{\mathrm{r}}$ was consistent with dissociation of the native trimer to monomers (Figs. 2 and 3). Other workers have reported observing both trimers and dimers in the same preparation $(9,27)$. In a study with PNP from chicken liver it was found that dissociation toward the dimer was promoted by diluting the enzyme to $<3 \mu \mathrm{g} / \mathrm{ml}$ (27). At that concentration PNP was also partly dissociated in our studies. These data are all consistent with PNP being a dissociating enzyme, where the dissociation process is sensitive both to enzyme concentration and to the presence of appropriate ligand effectors. This may be a fairly general indicator for allosteric regulation, since $15 \%$ of all the enzymes involved in nucleotide metabolism are dissociating enzymes (28).

Based on the final specific activity of PNP from different sources and on the corresponding purification fold, in most eukaryotic sources the in vivo concentration of PNP is generally in the range of $20-100 \mu \mathrm{g} / \mathrm{ml}(0.7-3.5 \mu \mathrm{M})$ or even greater. The enzyme used in the present study clearly exists as a trimer at such concentrations (Figs. 2 and 3), and this confirms earlier reports for calf spleen PNP $(3,7)$. Previous papers have not always reported enzyme quantities used for molecular weight studies. It is therefore possible that observations of PNP as a dimer or monomer (13-16) are the natural result of a more diluted enzyme preparation. Although many enzymes change their polymeric assembly in response to ligands, only a very few have been shown to dissociate to a more active monomer in response to a substrate. Examples are cysteine synthetase (Salmonella typhimurium) (29), isocitrate dehydrogenase (Blastocladiella emersonii) (30), homoserine dehydrogenase (Rhodospirillum rubrum) (31), and cAMP-dependent protein kinase (rabbit muscle) (32).

Enzyme Stability_-The stability of the enzyme is very dependent on enzyme concentration, temperature, and the presence of appropriate ligands (Figs. 5 and 6). Since the diluted enzyme \pm a stabilizing substrate showed a steady loss of activity during short term preincubation (Fig. 5), it may be changing to less active conformations. Because of these observations, for the gel permeation chromatography studies enzyme was always prepared freshly in the appropriate buffer (at a concentration of $10 \mu \mathrm{g} / \mathrm{ml}$ ) and applied to the column within $30 \mathrm{~min}$. There was no evidence that inosine caused dissociation of the native trimer. But since at the same concentration of enzyme the specific activity of enzyme preincubated with phosphate was always a little higher, then $P_{i}$ must produce a more active conformation.

The catalytic reaction for PNP follows an ordered sequential mechanism $(13,22,33)$.

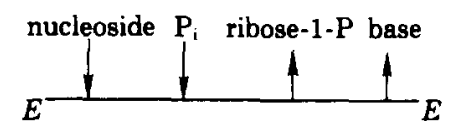

Therefore, phosphate should not bind significantly at the catalytic site in the absence of the nucleoside co-substrate, and in preincubation studies inosine should bind at the catalytic site, while $\mathrm{P}_{\mathrm{i}}$ should only bind at a separate site.

The lag studies (Fig. 7) also give evidence of different conformational states. Note that the enzyme, in whatever preincubation environment, was never instantaneously active since it normally took $30 \mathrm{~s}$ to combine the reaction components, and then there was still an observable lag period before product formation became measurable.

Cooperativity-The responses of the enzyme to phosphate were complex and therefore support a model of at least two different sites for binding phosphate. Kinetic studies show an $S_{0.5}$ value for phosphate of $3.1 \mathrm{mM}$, with activity reaching a maximum at about $30 \mathrm{~mm}$. However, dissociation did not begin until $\mathrm{P}_{\mathrm{i}}$ was at $55 \mathrm{mM}$, and for dissociation the $L_{0.5}$ is $88 \mathrm{mM}$. Furthermore, enzyme activity in response to $P_{i}$ showed negative cooperativity, while dissociation in response to $P_{i}$ showed unusual positive cooperativity. All these results suggest that a distinct site, separate from the catalytic site and with a lower affinity for phosphate, mediates the conformational change seen as dissociation. Additional support for a separate regulatory site for $\mathrm{P}_{i}$ comes from the fact that the dissociation studies were done in the presence of $P_{i}$ alone, such that $P_{i}$ should not interact significantly at the catalytic site in promoting dissociation.

In the description of the three-dimensional crystal structure for human PNP (23), it was observed that there are probably two distinct phosphate-binding sites, though the authors were uncertain if the second site was mechanistically significant. Our data support the existence of two phosphate-binding sites, and the results show that each site can lead to a conformational change in the enzyme. Binding at site 1 , the high affinity catalytic site, produces cooperativity in response to the substrate; binding at site 2 , a lower affinity regulatory site, leads to a conformational change that produces dissociation of the enzyme as well as a higher specific activity.

The physiological relevance of site 2 is not clear. For mammals, cellular phosphate concentrations have been re- 
ported at $0.4-6 \mathrm{mM}(34-37)$. These values correspond well to the kinetic cooperativity observed (Fig. 4) but suggest that intracellular $P_{i}$ would never be high enough to produce dissociation of PNP. It is possible that $P_{i}$ simply acts as an analog for an unknown physiological allosteric regulator that has much better affinity at site 2 .

An important observation of these studies is that the enzyme monomer is not only active but appears to have a higher intrinsic catalytic rate than the trimer. In analyzing the threedimensional human PNP structure, it was judged that the catalytic site in each subunit is partly formed by one loop from the nearest adjoining subunit (23). However, this interaction with the neighboring subunit may not be optimal for activity. Our results are consistent with a polymer in which all subunits are not equally or fully active, since both diluted and concentrated PNP reactions show negative cooperativity. Phosphate may produce its effect by such possible mechanisms as: a conformational change in the trimer, or dissociation toward a more active monomer, or by mechanistic coupling between two sites on the same subunit. However, both dissociation and conformational changes may contribute to the observed response of the enzyme to substrates in vitro.

A simple scheme to account for the observed results shows the enzyme to be a stable trimer with low specific activity. Dissociation leads to the monomer with maximum activity. The monomer appears less stable, and is more subject to denaturation and loss of activity.

$$
{ }_{\downarrow}^{1^{*}} \rightleftharpoons \underline{3}^{\circ}
$$

The literature suggests an enzyme with considerable variety in polymer size and the presence of cooperativity when PNP is prepared from different sources. We are inclined to the opposite interpretation; the enzyme from most or all eukaryotic sources is probably quite similar in subunit size, polymer size, and kinetics. The present work, as well as studies cited, shows how differing results for the native size and many kinetic parameters are easily produced by the in vitro concentration of enzyme and appropriate ligands, as well as by the temperature of the enzyme preparation.

Acknowledgment-We wish to thank Allen Poma for efficient technical assistance.

\section{REFERENCES}

1. Parks, R. E., Jr., and Agarwal, R. P. (1976) in The Enzymes (Boyer, P. D., ed) Vol. 7, pp. 483-514, Academic Press, New York

2. Stoeckler, J. D., Ealick, S. E., Bugg, C. E., and Parks, R. E., Jr. (1986) Fed. Proc. 45, 2773-2778

3. Stoeckler, J. D., Agarwal, R. P., Agarwal, K. C., Schmid, K., and Parks, R. E., Jr. (1978) Biochemistry 17, 278-283

4. Zannis, V., Doyle, D., and Martin, D. W., Jr. (1978) J. Biol. Chem. 253, 504-510
5. Osborne, W. R. A. (1980) J. Biol. Chem. 255, 7089-7092

6. Ghangas, G., and Reem, G. H. (1979) J. Biol. Chem. 254, 42334237

7. Edwards, Y. H., Edwards, P. A., and Hopkinson, D. A. (1973) FEBS Lett. 32, 235-237

8. Ikezawa, Z., Nishino, T., Murakami, K., and Tsushima, K. (1978) Comp. Biochem. Physiol. 60B, 111-116

9. Milman, G., Anton, D. L., and Weber, J. L. (1976) Biochemistry 15, 4967-4973

10. Umemura, S., Nishino, T., Murakami, K., and Tsushima, K. (1982) I. Biol Chem 257, 13374-13378

11. Savage, B., and Spencer, N. (1977) Biochem. J. 167, 703-710

12. Anan'ev, A. V., Bezirdzhyan, K. O., and Akopyan, Z. I. (1988) Biochemistry 52, 1749-1756 (translated from Biokhimya)

13. Lewis, A. S., and Glantz, M. D. (1976) Biochemistry 15, 44514456

14. Lewis, A. S., and Lowy, B. A. (1979) J. Biol. Chem. 254, 99279932

15. Lewis, A. S. (1978) Arch. Biochem. Biophys. 190, 662-670

16. Lewis, A. S., and Glantz, M. D. (1976) J. Biol. Chem. 251, 407413

17. Choi, H.-S., Stoeckler, J. D., and Parks, R. E., Jr. (1986) J. Biol. Chem. 261, 599-607

18. Tuttle, J. V., and Krenitsky, T. A. (1984) J. Biol. Chem. 259, $4065-4069$

19. Moyer, T. P., and Fischer, A. G. (1976) Arch. Biochem. Biophys. 174, 622-629

20. Bezirdzhyan, K. O., Kocharyan, S. M., and Akopyan, Z. I. (1988) Biochemistry 52, 1526-1532 (translated from Biokhimya)

21. Murakami, K., and Tsushima, K. (1975) Biochim. Biophys. Acta 384, 390-398

22. Krenitsky, T. A. (1967) Mol. Pharmacol. 3, 526-536

23. Ealick, S. E., Rule, S. A., Carter, D. C., Greenhough, T. J., Babu, Y. S., Cook, W. J., Habash, J., Helliwell, J. R., Stoeckler, J. D., Parks, R. E., Jr., Chen, S., and Bugg, C. E. (1990) J. Biol. Chem. 265, 1812-1820

24. Kalckar, H. M. (1947) J. Biol. Chem. 167, 429-443

25. Read, S. M., and Northcote, D. H. (1981) Anal. Biochem. 116, 53-64

26. Kurganov, B. I. (1982) Allosteric Enzymes, John Wiley \& Sons, New York

27. Mora, M., and Bozal, J. (1985) Comp. Biochem. Physiol. 82B, $805-813$

28. Traut, T. W. (1988) CRC Crit. Rev. Biochem. 23, 121-169

29. Cook, P. F., and Wedding, R. T. (1978) J. Biol. Chem. 253, 78747879

30. LéJohn, H. B., McCrea, B. E., Suzuki, I., and Jackson, S. (1969) J. Biol. Chem. 244, 2484-2493

31. Mankovitz, R., and Segal, H. L. (1969) Biochemistry 8, 37573764

32. Reimann, E. M., Walsh, D. A., and Krebs, E. G. (1971) J. Biol. Chem. 246, 1986-1995

33. Agarwal, R. P., and Parks, R. E., Jr. (1969) J. Biol. Chem. 244, 644-647

34. Simonsen, L. O., and Cornelius, F. (1978) Biochim. Biophys. Acta 511, 213-223

35. Akerboom, T. P. M., Bookelman, H., Zuurendonk, P. F., van der Meer, R., and Tager, J. M. (1978) Eur. J. Biochem. 84, 413420

36. Bowen, J. W., and Levinson, C. (1982) J. Cell. Physiol. 110, 149154

37. Pilz, R. B., Willis, R. C., and Boss, G. R. (1984) J. Biol. Chem. 259, 2927-2935 